\title{
FELHŐBEN AZ EGÉSZSÉGÜNK
}

\section{Szerzők:}

\author{
Szabó Dániel Dénes \\ Medgyessy Ferenc Gimnázium, \\ Mûvészeti Szakgimnázium és Technikum \\ Pirint Róbert Olivér \\ Debreceni Ady Endre Gimnázium \\ Első szerző e-mail címe: \\ szabodanieldenes@gmail.com
}

\author{
Lektorok: \\ Ujvári Balázs (PhD) \\ Debreceni Egyetem \\ Borbélyné Bacsó Viktória (PhD) \\ Medgyessy Ferenc Gimnázium, \\ Múvészeti Szakgimnázium és \\ Technikum \\ ...és további két anonim lektor
}

\begin{abstract}
Absztrakt
A tanulmányban bemutatásra kerül egy városi levegő-minőségmérést végző, a mé-rőállomások adatait valós időben feldolgozó hálózat koncepciója, s kialakításának kezdeti eredményei. A mért infomációk alapján előrejelzések tehetők, illetve javaslatok fogalmazhatók meg a forgalom szervezésével, a zöld területek kialakításával, a városok körül lévő védősávok elhelyezésével, esetlegesen szükséges környezetvédelmi és egészségügyi intézkedésekkel kapcsolatban.
\end{abstract}

Kulcsszavak: levegőminőség, környezetvédelem

Tudományterület: fizika, biológia, informatika

\section{Abstract \\ OUR HEALTH IN THE CLOUD}

The study presents the concept of an urban air quality measurement network, which processes the data of the measuring stations in real time, and the initial results of its development. Based on the measured information, forecasts can be made and proposals can be made in connection with the organization of traffic, the creation of green areas, the location of buffer strips around cities, and any necessary environmental and health protection measures.

Keywords: air quality, environmental protection

Disciplines: physics, biology, informatics

Szabó Dániel Dénes és Pirint Róbert Olivér (2020): Felhőben az egészségünk. Mesterséges intelligencia - interdiszciplináris folyoirat, II. évf. 2020/2. szám. 73-86. doi: 10.35406/MI.2020.2.73 
Manapság rendkívül nagy problémát jelent a levegő minősége a fejlődő és a fejlett országokban egyaránt. A WHO (Világ Egészségügyi Szervezete) statisztikái alapján évente legalább 8 millió haláleset kötődik a szennyezett levegőhöz. 10 emberből legalább 9-en olyan helyen élnek, ahol a légszennyezés értéke meghaladja az egészségügyi kockázattal járó értéket. Hasonlóan problematikus egészségügyi rizikóról kapunk képet az Európai Környzeeti Ügynökség dokumentumaiból (European Environment Agency, 2011, 2012, 2019), egyéb kutatásokból (például: (Kim, 2015; Raaschou-Nielsen és tsai, 2016). Ez az egészségügyi kockázat számos megbetegedéshez vezethet, valamint immunrendszerünket gyengítve, fenyegetésnek vagyunk kitéve potenciális vírusok számára. Ezt a számot jelentősen csökkenthetjük azonban, ha fel-, majd megismerjük a problémát és a tapasztalati törvényszerűségeit. Azonban sajnos, a szállópor, a levegőminőség napjainkig sem teljesen körbejárt tudományterület, mivel számtalan komponens játszik közre, melyek között található egyaránt gáz és szilárd halmazállapotú anyagok is. Ezek hatásait saját bőrünkön is tapasztalhatjuk. Például nagyvárosok kül- és belvárosában kerékpározva, nagyobb utak mellett haladva gyakran kaphatunk köhögőrohamokat a levegő szennyezettsége miatt. Projektünkben e probléma megoldására szántuk el magunkat. Rövid kutakodás után arra eszméltünk rá, hogy Magyarországon a levegő minősége kifejezetten rossz, gyakran egészségügyi kockázatot is jelent az emberek számára. Egyes források szerint, gyakran megközelíti a kínai levegőt, ami egyenlő azzal, mintha két doboz cigarettát szívnának el. Azonban meg akartunk mi is erről győződni, valamint ha valóban ilyen szörnyű a helyzet, megoldást szerettünk volna találni arra, hogy mi mit is tehetünk ez ellen. Ezen gondolatmenet során jutottunk el addig a koncepcióig, hogy létrehozunk egy olyan mérőállomásokból álló alulról szerveződő hálózatot Debrecen városában, ami adatokat gyűjt a levegő minőségéről, szállóporról valamint hőmérsékletről és páratartalomról, amiket valós időben eljuttat szerverünkre. Későbbiekben ezen adatokat felhasználva hasonlóságon alapuló előrejelzé-seket tudunk tenni, valamint megfigyelhetünk tapasztalati törvényszerūségeket.

\section{Eszközök}

Számos szenzort kipróbáltunk, mivel mérhetnénk a szállóport. Volt olyan szenzor, ami egy kisebb kalibrálás után tökéletesen végezte a dolgát, azonban voltak kevésbé sikeresek, például egy szenzornál megfigyeltük, hogy a szállópor értékét a mérőeszköz a tárgyak közelsége alapján határozta meg (1. kép).

\section{1. kép. Szállópor méröeszköz. Forrás:}

wikimedia.org.

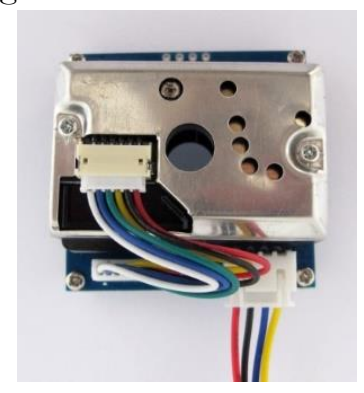


A tesztek után első választásunk az MQ2 levegőminőség szenzorra (2. kép) esett, amit kalibráltunk úgy, hogy szállópor mérésére legyen alkalmas, melynek menetéről a későbbiekben olvashatnak.

\section{2. kép. MQ2 levegöminöség szenzor. Forrás:} ebay.com

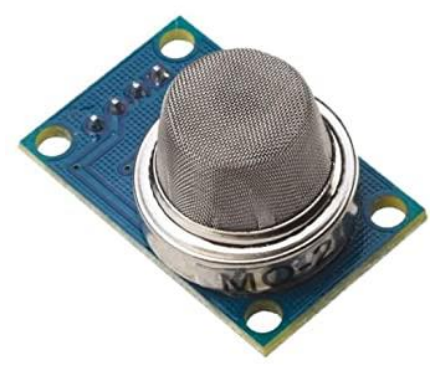

A szenzor jellegzetessége, hogy melegszik, mivel a benne található fütőszál segítségével kiüríti a leülepedő anyagokat. Emiatt azonban bekapcsolása után várnunk kell bizonyos ideig, valamint különböző hőmérsékleti mérések között jelentős különbség van, ezért a hőmérsékleti tényezôvel kell számolnunk a kapott adatokat. Viszonylag széles intervallumban képes érzékelni a levegőben lévő különböző részecskéket, 300 és 10000 ppm között. Azért választottuk ezt a szenzort, mivel rendkívül költséghatékony, kevés áramfelvételre van szüksége, emellett rendkívül kisméretű, és egy kalibrálás után megbízható. Azonban az MQ2-nek volt egy hiányossága: nem volt alkalmas nagyobb szállóporkomponensek mérésére, mint például 2,5 mikrométer vagy a 10 mikrométer körüliek, ezzel főleg az égetés, kipufogás közben keletkezett molekulányi szennyezőanyagok mutathatóak ki jól. Szerencsére projektünk során viszont megfizethetőbbé vált egy másik szenzor is a Nova SDS011 Dust Sensor (továbbiakban Nova - 3. kép).

\section{3. kép. Nova SDS011 Dust Sensor. Forrás:} reichelt.com

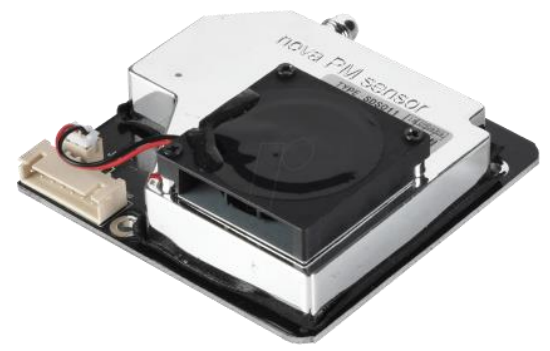

Ez a mérôeszköz már megfelelő volt az 1 és 2,5 mikrométer közötti (PM2.5) tartomány érzékelésére, és 2,5 mikrométer és 10 mikrométer közötti (PM10) tartomány mérésére is. Természetesen ezt a szenzort is teszteltük, valamint némi kalibrálásra is szorult, viszont sokkal pontosabbnak véltük, mint az MQ2-t, mivel a felbontása 0,3 $\mu \mathrm{g} / \mathrm{m} 3$, ami egy 0-999,9 $\mu \mathrm{g} / \mathrm{m} 3$ mérési tartományban értendő. Azonban az előző mérőeszközhöz képest, volt néhány hátránya is a váltásnak, például a Nova-ban található ventilátor miatt megnövekedett a mérőállomásunk áramfelvétele (körülbelül 70土10 mA 5V feszültség mellett), valamint kevésbé volt kompakt nagyobb méretéből adódóan. Emellett, hogy még többféle adat álljon rendelkezésünkre, felhasználtunk méréseink során egy szén-dioxid mérô szenzort is. Ez az MH-Z19B szenzor (4. 
kép) volt, ami \pm 50 ppm pontossággal képes mérni a levegő szén-dioxid koncent-rációját, és ez egy 0 és 5000 ppm közötti tartományban történik.

\section{4.kép. MH-Z19B sz̨enzor. Forrás: alibaba.com.}

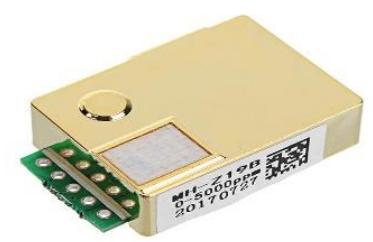

Fontos tudni, hogy ennek az eszköznek is jellegzetessége a felmelegedés, mivel így akadályozza meg a szenzor, hogy a különböző gázok leülepedjenek a műszerben, ezért bekapcsolás után pontos adatokért várnunk kell egy bizonyos ideig. Ezt az eszközt azonban nem kellett kalibrálnunk, mivel gyárilag kalibrált. További adatgyújtés érdekében hőmérsékletet is páratartalmat mértünk a HDC1080 szenzorral (5. kép), ami a Texas Instruments terméke. Ez az eszköz rendkívül apró, leghosszabb éle mindössze 3 milliméter hosszú. A hőmérsékletet $\pm 0,2{ }^{\circ} \mathrm{C}$, míg a páratartalmat $\pm 2 \%$ pontossággal képes mérni.

\section{5. kép. HDC1080 szenzor. Forrás: alibaba.com}

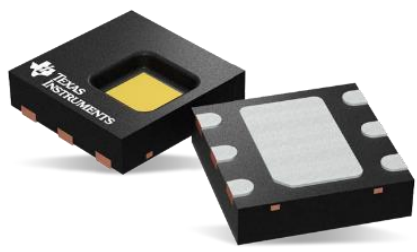

Ezeket az eszközöket próbáltuk a lehető legkompaktabbá tenni, ezért a Nován kívül mindegyik műszert egy NYÁK-ra tettük (6.kép), egyúttal ezzel elérve, hogy a jeltovábbítás a lehető legkevesebb helyen sérülhessen. A NYÁK megtervezésében segítségünkre volt a Debreceni Egyetem Fizikai Innovációs Mühelye.

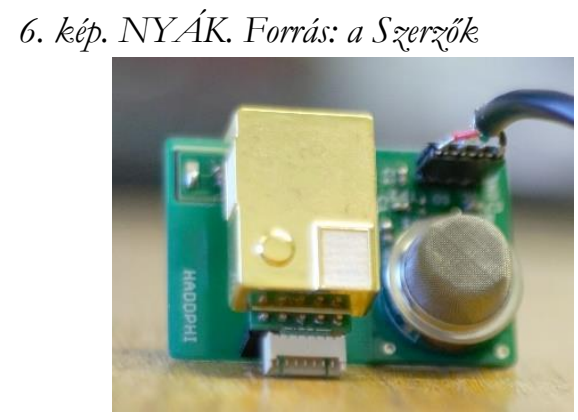

Mielőtt ezeket az eszközöket kivittük volna a szabadba, szereznünk kellett egy vázat, ami ellenáll a környezet viszontag-ságainak, azonban légáteresztő. A váz megalkotásához a 3D nyomtatás módszerét választottuk, egy korábbi projektünkben elkészített saját fejlesztésű nyomtatóval készítettük el az Autodesk Inventor-ban tervezett vázat. Két vázat alkottunk, mivel projektünk kezdetén nem volt számításban a Nova. Az MQ2-nek egy kifejezetten légáteresztő vázat terveztünk (7. kép), mivel a műszer nem biztosítja magának a légáramlást. Ekkor alkottuk meg a projektünk nevét, a WeCair-t, mely rá is került az első nyomtatott vázunkra is. 


\section{7. kép. WeCair. Forrás: a Szzerōôk}

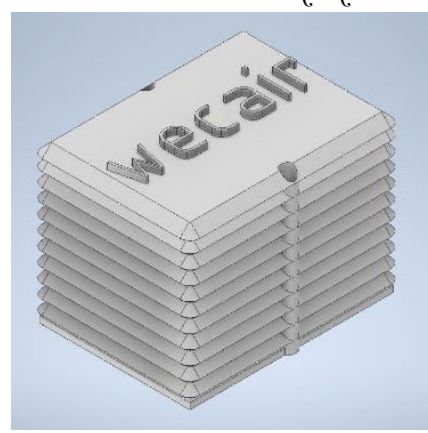

Azonban változtatnunk kellett a terveken, mivel a vázba kellett intergrálni a Novát is, ami egy sokkal nagyobb méretű eszköz. Ezért egy négy részből álló vázat alkottunk (8. kép), melyet négy darab 3 milliméteres csavarral, valamint ezekre való anyával könnyedén össze lehet fogatni (9. kép).

\section{8. kép. Négy részuból álló váz. Forrás: a Szerzőo}

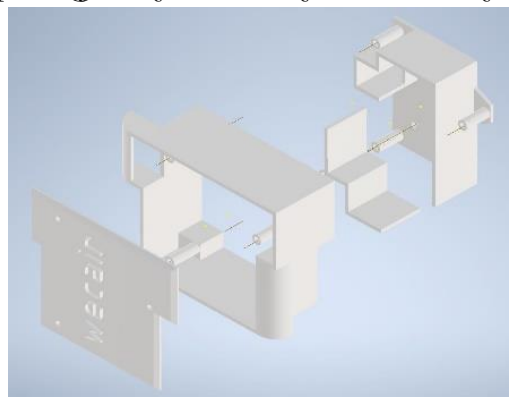

\section{9. kép. A Nova váza. Forrás: a Szerzooók}

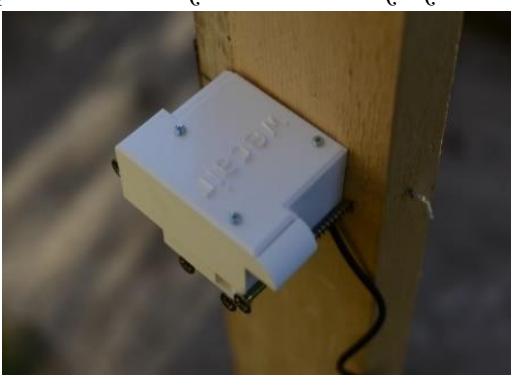

Ez a váz azonban kevésbé légáteresztő, mivel a Nova ventilátorja biztosítja a megfelelő légáramlást a vázon belül, így nem ülepedik le anyag a szenzorokban, valamint nem történik túlmelegedés. A váz úgy lett kialakítva, hogy a Nova a felső lap aljára kerüljön, ezzel a ventilátor része kerüljön alulra. Ez azért volt fontos, mivel így a kiürítésben nem csak a légáramlás, hanem a gravitáció is a segítségünkre van, ezzel elősegítve a műszer múködését. Valamint csakúgy, mint az MQ2-es váznál, itt is egy tokrészbe kell becsúsztatni a NYÁK-ot, majd egy illesztéssel odarögzíteni, hogy ne történjen mozgás a vázon belül.

Másik nagy kérdés volt számunkra, hogy hogyan oldhatnánk meg a valós idejű adattovábbítást, azonban találtunk egy kiárusításban lévő erre alkalmas eszközt (ami miatt rendkívül olcsón jutottunk hozzá), a Logilink ua0175-öt (10. kép).

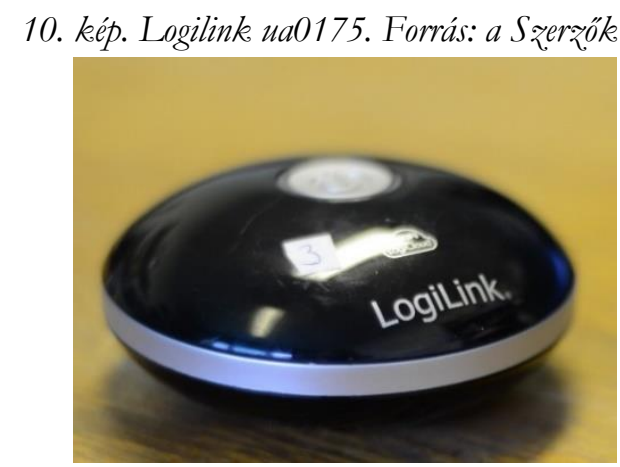

Ez egy elég sokoldalú műszer, hiszen hordozható külsô tároló, található benne egy akkumulátor, amiről pár órán át múködtetni képes rendszerünket, valamint WiFi 802.11 $\mathrm{b} / \mathrm{g} / \mathrm{n}$ átvitel kezelésére is alkalmas ez az 
eszköz, ezzel pedig vezeték nélküli kapcsolaton keresztül alkalmas fájlok megosztására. Azonban ezt az eszközt módosítottuk sok helyen, és eközben véltük felfedezni a belső címkén, hogy „UFO” névvel illették a gyártók, valószínúleg alakja miatt, így a továbbiakban így lesz róla szó. Néhány elektronikai módosítás után lecserél-tük az eredeti firmware-t linux/unix alapú operációs rendszerre, így az eszközünk egy WiFi-s adatfeldolgozó és továbbító kis számítogéppé vált.

A teljes adattovábbítási kör a szenzorok méréseinél kezdődik, amit kábelen tovább küld az UFO-ra, ami rá van csatlakozva egy vezetéknélküli hálózatra, ami internetelérés mellett továbbítja adatainkat a szerverünkre, ami egy Raspberry Pi. Ezeket az adatokat majd egy MySQL adatbázisba rendezve tá-rolja, dátummal együtt.

A teljes mérőállomás ára árfolyamtól függő, azonban körülbelül 25000 forint körül mozog jelenleg. Ennek az árnak nagy részét a Nova teszi ki, mivel körülbelül 9 ezer forintba kerül, míg az MQ2 1000 forintba, a szén-dioxid mérô 6000 forint körül, a NYÁK gyártása körülbelül 400-500 forint, az UFO körülbelül 5000 forintba kerül, míg a 3D nyomtatás anyagköltsége 400-500 forint között van. Ezeknek az anyagi hátterét a Nemzeti Tehetség Program biztosította.

\section{Kalibráció}

Munkánk szerves részét képezte a kalibráció, mivel sok múszer, amivel dolgo-zunk enélkül olyan, mint egy beskálázatlan hő- mérō. Azért, hogy hiteles legyen a kalibrálásunk, szükségünk volt valami megbízható referenciaműszerre. A Debreceni Atommagkutató Intézettől ennek érdekében kölcsön kaptunk egy rendkívül pontos, azonban nagyon drága mûszert, ami egy széles méréstartományú mini aeroszol spektrométer, aminek típusa: OPS M3330 (11. kép).

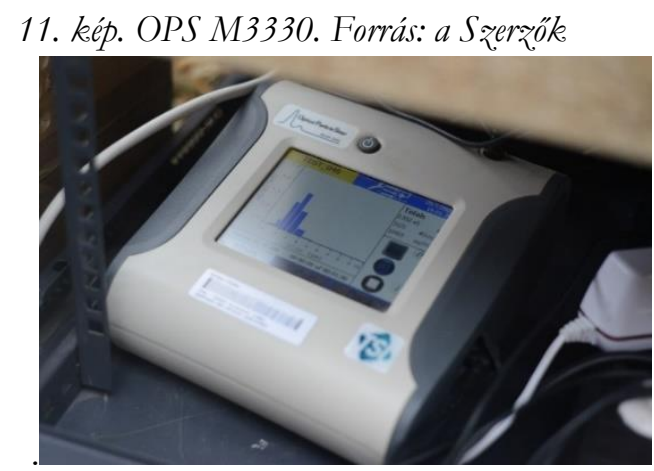

Ez az eszköz annyira pontos, hogy képes még azokat a szállóporkomponenseket is érzékelni, amik már bőrünkön is átjuthatnak, azaz kisebb, mint 1 mikrométer átmérőjűek. A műszer tud akkumulátorról is mûködni, ennek köszönhetően a szabadban is hasz-nálhattuk. Mivel 0,3 és 10 mikrométer közötti szállóporkomponenseket mér, ezért másféleképpen voltak felosztva a tartományok, nem a hagyományos PM10, PM2,5 és PM1-ként volt feltüntetve, hanem ezek sok kis részre voltak felosztva, ezért, hogy azonos dimen-zióban mérjen eszközeinkkel, átállítottuk ezekre a tartományokra, ami habár felbontásveszteséggel járt, nem volt mérvadó, hiszen a műszereink is ezekben mértek. 
Az eszközök kalibrálási mérése egy több napon át tartó mérés volt, mivel ekkor kapunk elég adatot ahhoz, hogy megfelelően normálni tudjuk az adatok által leírt görbéket, valamint szükség volt erre a hosszú mérésre, mivel az MQ2 egyik jellegzetessége, hogy első bekapcsoláskor egy napig égeti kifelé az érzékelőjét, ezzel kalibrálva önmagát.

A kalibrálás során különböző kísérleteket hajtottunk végre, hogy össze tudjuk hangolni mérőállomásainkat. Ehhez egy zárt légtérbe, szorosan egymás mellett helyeztük el a műszereinket. Ezek után első kísérletként háztartási port szórtunk ki a műszereinkre (12.a. kép), azonban ezzel rájöttünk, hogy ez sajnos nem fog segíteni nekünk kalibráció során, mivel az eszközeink nem reagáltak erre, ezek túl nagyméretű szemcsék.

Következőként ezért egy sokkal apróbb kompo-nensű porral próbálkoztunk, egy eléggé megviselt teherautó légszűrőjét poroltuk ki (12. b. kép), ami nagy segítséget jelentett számunkra, mivel egyaránt PM2,5 és PM10-et is mértünk.

Következő kísérletünk, amikor egy szivacsból krétaport (12. c.kép) szórtunk műszereinkre, szintén hasonló eredményeket mutatott, azonban itt túlsúlyt tapasztaltunk a PM10 javára. Ezek után kivittük a szabadba egy jól lezárt fémdobozba az eszközeinket, és a doboz ajtaját kinyitva, ráálltunk egy autóval, hogy a kipufogott füstöt érzékelje (12.d. kép). Mivel ez dízel autó volt, túlsúlyt vártunk a PM2,5 irányába, ami be is igazolódott.
12. a., b. c. d. kép. A kalibrálás folyamata. Forrás: a Szerzök
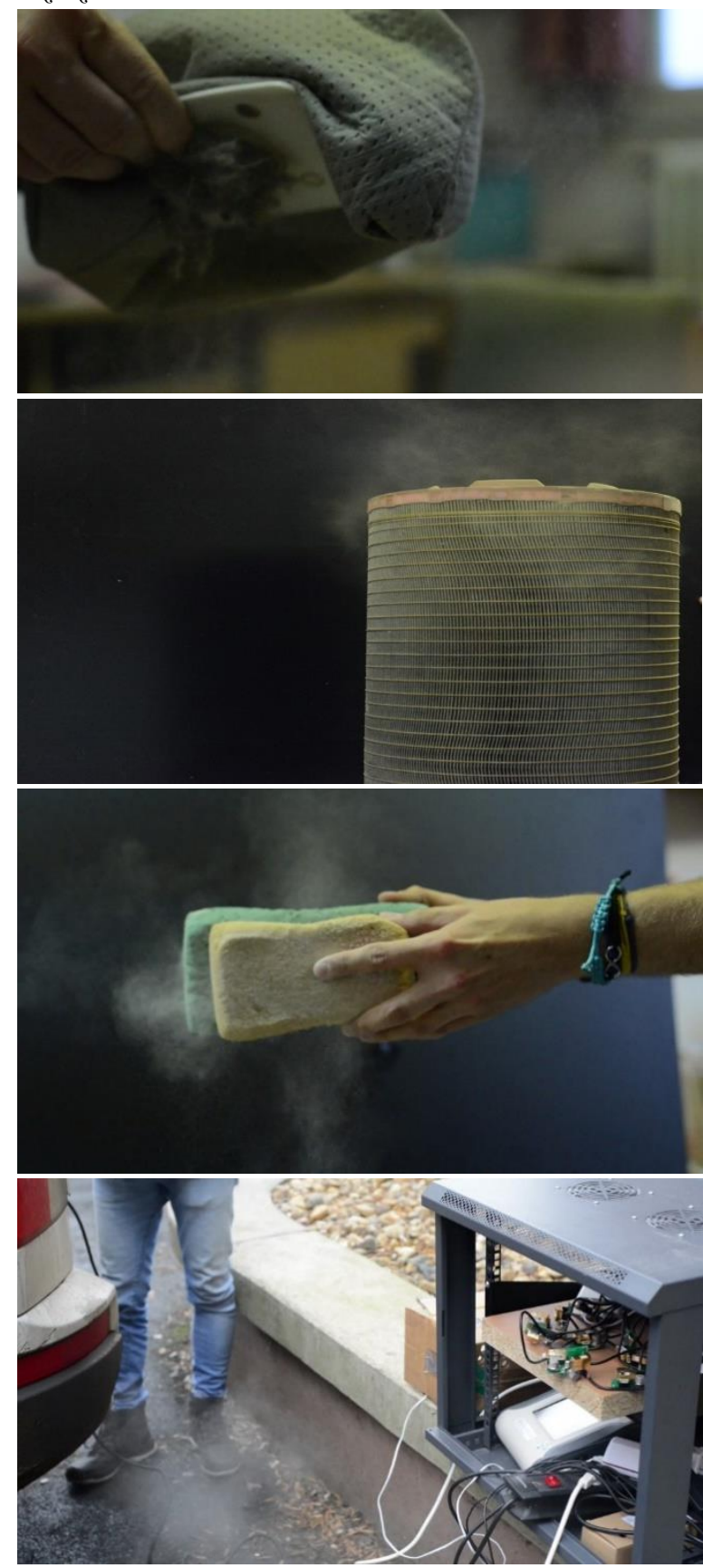
A mérések után elkezdtük elemezni a görbéket. Itt tűnt fel számunkra a szén-dioxid szenzorunk önkalibráló sajátossága, mivel mind a 11 műszer hirtelen váltott át teljesen más értékre. Ezek után összehasonlítottuk a Nova, az MQ2, és az OPS 3330 mûszereinket. Első dolog, ami szembetűnô volt számunkra, hogy a PM2,5-es és a PM10-es tartományt az MQ2 egyáltalán nem érzékeli, valamint arra, hogy a Novákat csak össze kellett normálni az OPS 3330 által mért értékekhez, és máris múködőképes volt. Azonban az MQ2-nél ennél több dolgunk volt, hiszen a görbéken olyan transzformációt kellett alkalmaznunk, amivel egy síkba tudjuk hozni az OPS 3330 adataival.
Emellett a kalibrálás során döntöttünk úgy, hogy a Novát fel fogjuk használni a projektünk során, mivel a mérések megmutatták, hogy a PM2,5 és a PM10 értékeink nem mindig együtt mozognak (1. ábra). A PM10 sokkal hamarabb ülepszik le, míg a PM2,5 sokáig marad a légtérben, ezzel bebizonyítva a két szállóporkomponens sajátosságát is egyaránt. Azonban ennek ellenére fel fogjuk használni továbbra is az MQ2 méréseit, mivel ettől azt várjuk, hogy az egyéb gázok jelenlétével a különböző méretű szállópor komponensek eredetére tudunk majd következtetéseket levonni ezekkel az adatokkal.

\section{1. ábra. Kalibrálási mérések adatai. Forrás: a Szerzọo}

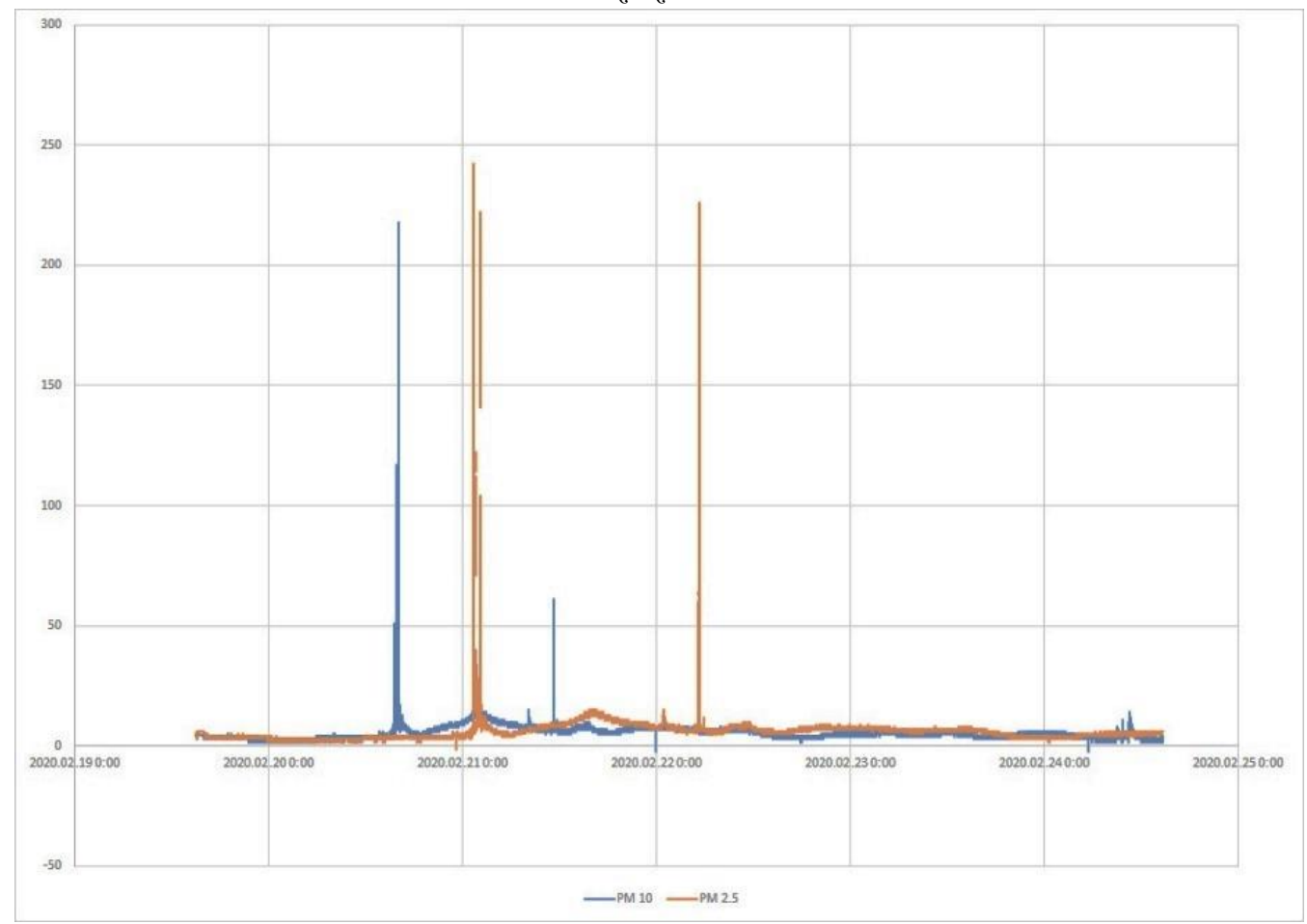




\section{A mérések eredménye}

Projektünk elején egy alulról szerveződő hálózatot akartunk kiépíteni Debrecen egyik külvárosában, ami annyiból állt volna, hogy mérőállomásainkat ismerőseinknél, barátainknál helyezzük el. A másik jelentősebb kísérletünk egy zárt udvarral körbevett iskola levegójének vizsgálata lett volna. Ezeket sajnos a járványügyi helyzet miatt nem tudtuk megvalósítani, mivel az iskoláink jelenleg nem üzemelnek, és a megrendelt 20 Nova szállóporszenzorból csak 6 jött meg 2 hónap csúszással, ezért otthonunkban építettünk fel egy mérőrendszert. Egy oszlopra 4 darab mérőállomást szereltünk fel félméterenként, amivel a szintek közti különbségeket akartuk szemléltetni (14. a kép). Az ötödik szenzort egy szélvédett, fedett részre helyeztük ki, ezzel a zárt udvart szimuláljuk (14. b. kép).

A forgalmat, mivel különösen nem frekventált helyen lakunk, egy fűnyíró által keltett kipufogógáz és az általa felvert por adta (2. ábra). Eközben, a hírek szerint a Kaszpitenger felől hatalmas port kavart egy vihar, ami Magyarországra is elért. Ezt a levegőminőség szenzoraink is képesek voltak kimutatni (3. ábra). Ezek mellett még a pár száz méterrel arrébb tevékenykedő bácsi gazégetéskor termelt füstjét is felvették eszközeink. Méréseinkből grafikonokat csináltunk, amelyekből az alábbi következtetéseket vontuk le: a homokviharnál elhanyagolható volt a kisebb méretû szállóporszemcsék száma, azonban a fünyíró használata közben illetve a gazégetésnél (4.ábra) nagyjából ugyanakkora növekedés ment végbe a pm 10 és pm 2,5 méretű porszemek koncentrációja között. Mindemellett, a fűnyíró okozta por és kipufogógáz ugyanúgy elért a fedettebb és a fentebb lévő mérôeszközökhöz is, de különböző koncentrációkban. Éjszakánként megfigyel-hető volt a környező háztartások fütése által generált füst is (5. ábra), ami körülbelül este nyolctól reggel nyolcig tartott. Az egyik délután a szomszéd üres telken traktorral mûvelték a földet, ez szintén szépen látszik a görbéken.
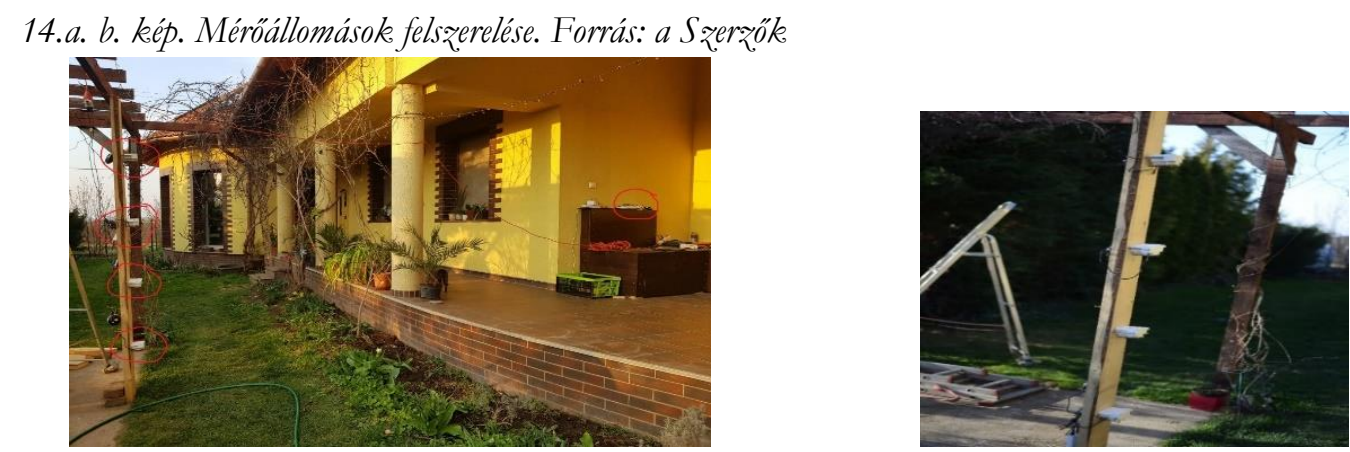
2. ábra. A fünyirás után keletkezett görbék 5 Novával mérve (az ötös szenzor a szélvédett helyen lévô. Forrás: a Szerző"k

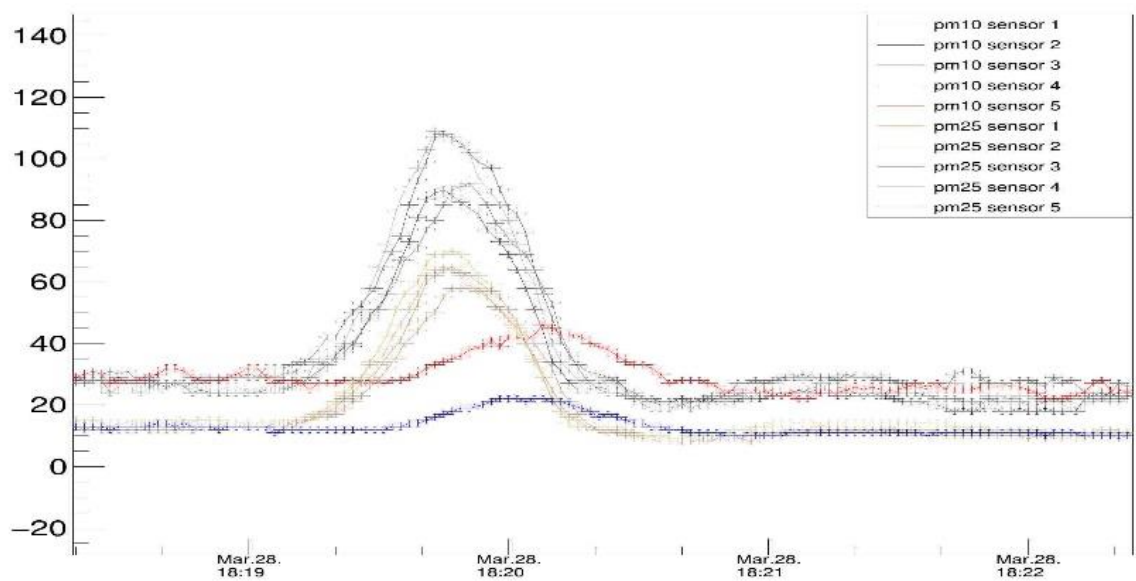

3. ábra. A Kaszpi-tenger közeli vihar miatt keletkezett görbék 5 Novával mérve (az ötös szuenzor a szélvédett helyen lévô). Forrás: a Szerzộk

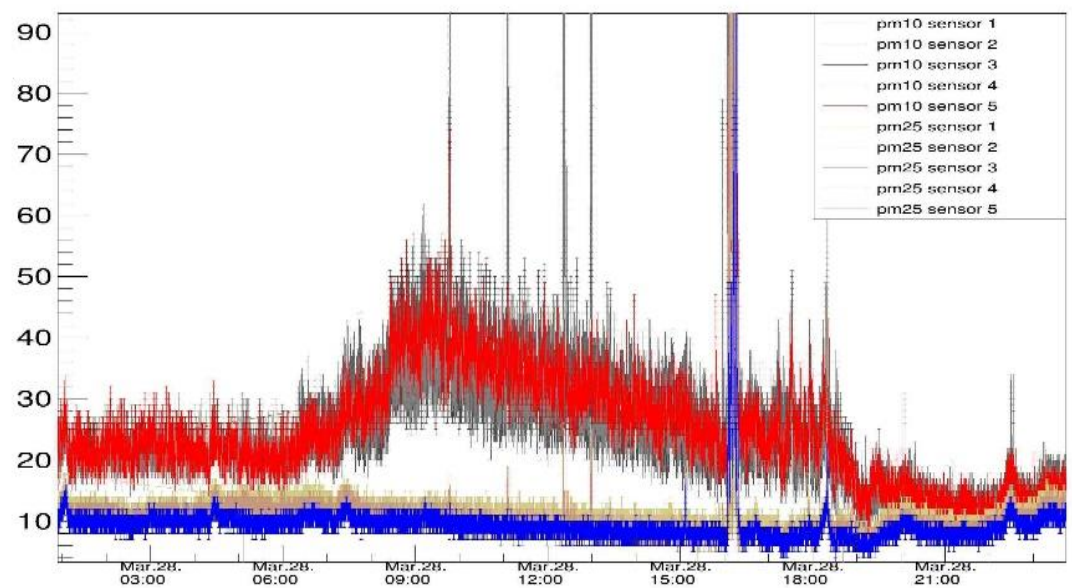


4. ábra. A fütés okozta csúcsosodások (az ötös szenzor a szélvédett helyen lévö). Forrás: a Sz̨erzőle

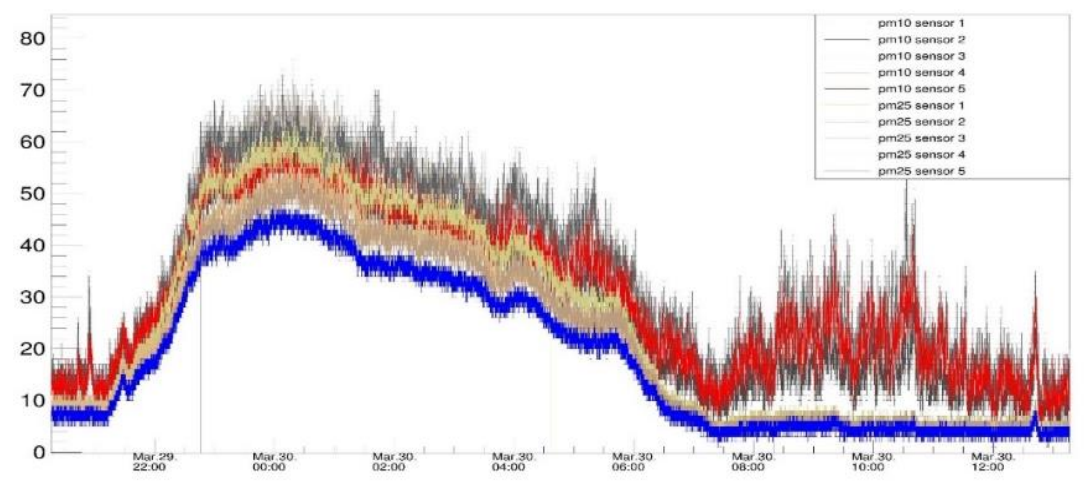

5. ábra. A gazégetés okozta csúcsosodások (azötös szenzor a szélvédett helyen lévô).Forrás: a Szerzőo

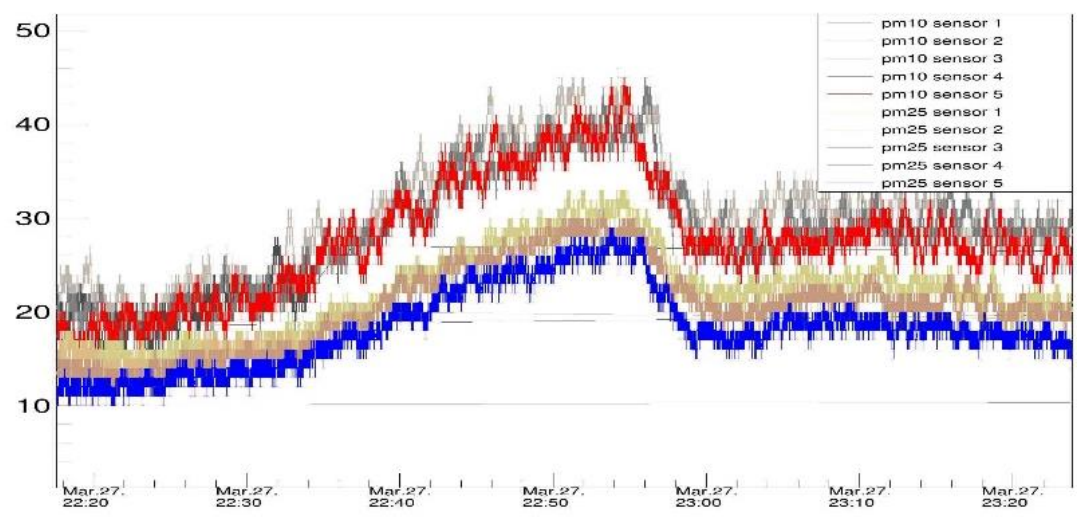

Az látszik, hogy általában mind a PM10 mind a PM2,5 megemelkedett és látszanak azok a csúcsok is, amikor a kerítéshez közel elhaladó traktor porfelhőbe burkolta műsze-reinket (6. ábra). A fokozatosan távolodó jármű egyre kisebb növekedést okozott, ezért kisebbek a csúcsok. A belső szenzor azonban minden esetben később jelzett, rávilágítva az elkülönítés jelentőségére.

\section{Előrejelzés}

Számtalan tényező játszik közre a szállópor és városi szmog alakulásában, legyen szó akár épületek nagyságáról és alakjáról, forgalomról, zöld területek befolyásáról, üzemanyagok minőségéről, vagy egyszerūen az időjárásról. Emiatt egyetlen egyenlettel nem lehet kiszámítani a por alakulását, ezért mi egy régebbi, de jól bevált módszert alkalmazunk. 
6. ábra A traktoros földmüvelés okozta csúcsosodások (az ötös szenzor a szélvédett helyen lévö). Forrás: a Szerzőlk

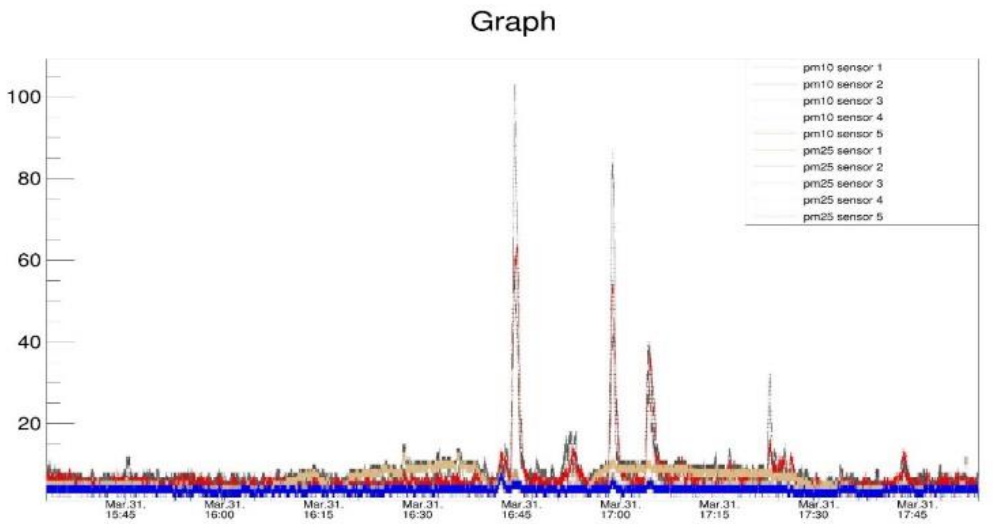

A XVIII. században a meteorológusok az aznapi adatait összevetették a korábbiakkal, és ha valami hasonlóságot véltek felfedezni, akkor a korábbi mérés grafikon görbéjét követve tett előrejelzést. Mi ugyanezt valósítjuk meg, azonban az emberi munka helyett egy algoritmust hoztunk létre ehhez. A népi megfigyelések is erre a metódusra alapozódnak. Vegyük példának a mai napot. A holnapi napnak szeretnénk megtudni a szállópor koncentrációját, ezért az algoritmusunk átnézi a múltbéli adatokat, és hasonlóságokat keres. Tételezzük fel, hogy a Sándor napi adatok nagyban hasonlítanak a mai adatokhoz, ezért a József napit hozzáillesztjük a mai naphoz, ezzel kész is az előrejelzésünk (7. ábra.).

Elegendő mérőrendszerrel egy városi épített környezetben a szállópor dinamikája hasonló ábrákkal leírható. Persze ehhez figyelembe kell vennünk más értékeket is (pél-dául hőmérséklet, páratartalom), de ezeket is mérjük. Valószínúleg nagy jelentősége lesz a meteorológiai paramétereknek is (légnyomás, szélerősség, csapadék, köd), amiket nyilvános adatbázisokból el fogunk tudni érni.

\section{Üzleti modellünk}

Ahhoz, hogy megismerjük egy Debrecen méretű város szállópor sajátosságait, több száz mérőállomásra lenne szükség. A kihe-lyezett állandó mérőállomások mellett, lenné-nek mobilis mérőállomásaink is, ezeket például biciklikre lehetne helyezni. Erre azért van szükség, hogy a közlekedésben fontos csomópontokat fel tudjuk mérni, emellett így mérni tudunk azokon a helyeken, ahol az emberek közlekednek, ami pontosabbá teszi a méréseinket, mint az állandó pontok átlagolása. Ezeket az információkat feldolgozva hasznos tanácsokat tudunk adni a forgalom szervezésére, illetve korlátozására, a zöld területek kialakítására, a városok körül lévő védősávok elhelyezésére. 
7. ábra. Az elörejelzés sematikus ábrája, kék szinnel jeleque a mai adatunkat, pirossal pedig a József napi adatunkat. Forrás: a Szerzök

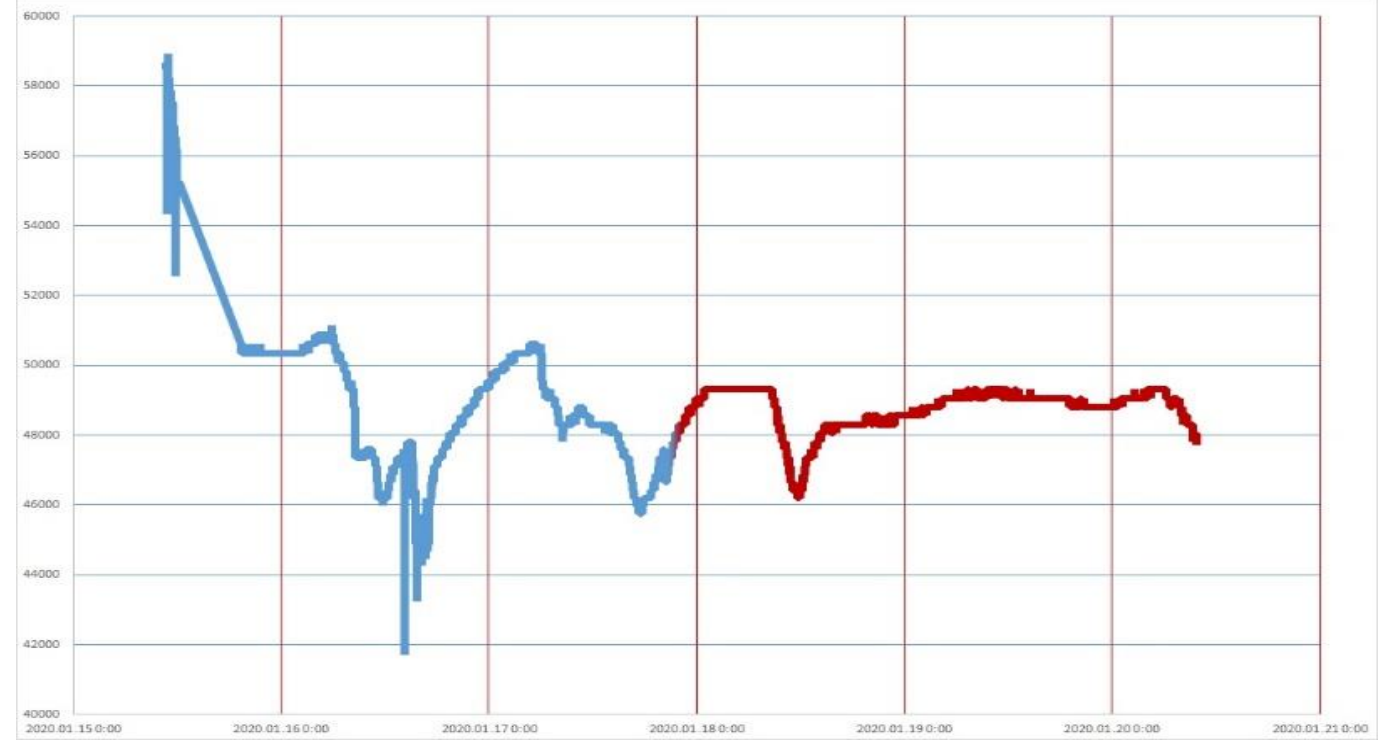

Azokon a területeken, ahol nem lehet lecsökkenteni a port, oda gyakrabban kell szűrővizsgálatokat kihelyezni. Hasonló intézkedésekkel évente számtalan életet lehet megmenteni, valamint rengeteg betegséget lehetne megelőzni.

Végezetül szeretnénk megköszönni a Debreceni Egyetem Fizikai Innovációs Kutatómúhelyének, valamint a Debreceni Atommagkutató Intézetnek a közremúködést és tanácsadást, emellett dr. Ujvári Balázsnak és Borbélyné dr. Bacsó Viktóriának a lektorálását.

\section{Irodalom}

European Environment Agency (2019): Air quality in Europe - 2019 report. Luxembourg: Publications Office of the European Union.

European Environment Agency (2011): Revealing the costs of air pollution from industrial facilities in Europe. Luxembourg: Publications Office of the European Union.

European Environment Agency (2012): Particulate matter form natural sources and related reporting under the EU Air Quality Directive in 2008 and 2009. Luxembourg: 
Publications Office of the European Union.

Kim, K.H., Kabir, E., Kabir, S., (2015): A review on the human health impact of airborne particulate matter. Environment International 2015/74, 136-143. Doi: 10.1016/j.envint.2014.10.005

Raaschou-Nielsen, O., Beelen, R., Wang, M., Hoek, G., Andersen, Z.J., Hoffmann, B., Stafoggia, M., Samoli, E., Weinmayr, G., Dimakopoulou, K., Nieuwenhuijsen, M., Xun, W.W., Fischer, P., Eriksen, K.T., Sørensen, M., Tjønneland, A., Ricceri, F., de Hoogh, K., Key, T., Eeftens, M., Peeters, P.H., Bueno-de-Mesquita, H.B., Meliefste,
K., Oftedal, B., Schwarze, P.E., Nafstad, P., Galassi, C., Migliore, E., Ranzi, A., Cesaroni, G., Badaloni, C., Forastiere, F., Penell, J., De Faire, U., Korek, M., Pedersen, N., Östenson, C.G., Pershagen, G., Fratiglioni, L., Concin, H., Nagel, G., Jaensch, A., Ineichen, A., Naccarati, A., Katsoulis, M., Trichpoulou, A., Keuken, M., Jedynska, A., Kooter, I.M., Kukkonen, J., Brunekreef, B., Sokhi, R.S., Katsouyanni, K., Vineis, P. (2016): Particulate matter air pollution components and risk for lung cancer. Environment International 2016/87, 66-73. Doi: $\underline{10.1016 / j . e n v i n t .2015 .11 .007}$ 